\title{
Genome mining of novel rubiginones from Streptomyces sp. CB02414 and characterization of the post-PKS modification steps in rubiginone biosynthesis
}

\author{
Jingyan Zhang ${ }^{1}$, Ying Sun ${ }^{2}$, Yeji Wang ${ }^{1}$, Xin Chen ${ }^{1}$, Lu Xue ${ }^{2}$, Jingjing Zhang ${ }^{2}$, Xiangcheng Zhu ${ }^{1,3,4}$,
} Yanwen Duan ${ }^{1,3,4^{*}}$ and Xiaohui Yan ${ }^{1,2^{*}}$ (I)

\begin{abstract}
Background: Rubiginones belong to the angucycline family of aromatic polyketides, and they have been shown to potentiate the vincristine (VCR)-induced cytotoxicity against VCR-resistant cancer cell lines. However, the biosynthetic gene clusters (BGCs) and biosynthetic pathways for rubiginones have not been reported yet.

Results: In this study, based on bioinformatics analysis of the genome of Streptomyces sp. CB02414, we predicted the functions of the two type II polyketide synthases (PKSs) BGCs. The rub gene cluster was predicted to encode metabolites of the angucycline family. Scale-up fermentation of the CB02414 wild-type strain led to the discovery of eight rubiginones, including five new ones (rubiginones J, K, L, M, and N). Rubiginone J was proposed to be the final product of the rub gene cluster, which features extensive oxidation on the A-ring of the angucycline skeleton. Based on the production profiles of the CB02414 wild-type and the mutant strains, we proposed a biosynthetic pathway for the rubiginones in CB02414.
\end{abstract}

Conclusions: A genome mining strategy enabled the efficient discovery of new rubiginones from Streptomyces sp. CB02414. Based on the isolated biosynthetic intermediates, a plausible biosynthetic pathway for the rubiginones was proposed. Our research lays the foundation for further studies on the mechanism of the cytochrome P450-catalyzed oxidation of angucyclines and for the generation of novel angucyclines using combinatorial biosynthesis strategies.

Keywords: Genome mining, Rubiginones, Cytochrome P450 hydroxylase, Biosynthesis

\section{Background}

Angucyclines are aromatic polyketides with an angular tetracyclic benz $[a]$ anthracene skeleton [1]. By virtue of their structural and functional diversity, angucyclines have greatly held the attention of chemists and biologists. Since the isolation of tetrangomycin from

\footnotetext{
*Correspondence: ywduan66@sina.com; yanxh@tjutcm.edu.cn

${ }^{1}$ Xiangya International Academy of Translational Medicine, Central South University, Tongzipo Road, \#172, Yuelu District, Changsha 410013, Hunan, China

Full list of author information is available at the end of the article
}

Streptomyces rimosus in 1965 [2], the number of angucyclines increased steadily, with more than 300 compounds discovered to date. The benz $[a]$ anthracene scaffold of angucycline is formed by folding a decaketide chain, which is biosynthesized by the type II polyketide synthases (PKSs), to generate the UWM6 intermediate [3]. This common intermediate is then decorated by various post-PKS modifications, such as oxidations $[4,5]$, ring rearrangement/contraction [6], and glycosylations [7, 8], to form numerous angucyclines. The angucyclines have original author(s) and the source, provide a link to the Creative Commons licence, and indicate if changes were made. The images or other third party material in this article are included in the article's Creative Commons licence, unless indicated otherwise in a credit line to the material. If material is not included in the article's Creative Commons licence and your intended use is not permitted by statutory regulation or exceeds the permitted use, you will need to obtain permission directly from the copyright holder. To view a copy of this licence, visit http://creativecommons.org/licenses/by/4.0/. The Creative Commons Public Domain Dedication waiver (http://creativeco mmons.org/publicdomain/zero/1.0/) applies to the data made available in this article, unless otherwise stated in a credit line to the data. 
various biological activities, such as antibacterial, anticancer, antiviral, enzyme inhibition, and platelet-aggregation inhibition [9].

Rubiginones, a subgroup of the angucycline family, were first isolated from Streptomyces griseorubiginosus No. Q144-2 in a screening program for potentiators of vincristine (VCR) cytotoxicity [10]. Six components, i.e., rubiginones $A_{1}, A_{2}, B_{1}, B_{2}, C_{1}$, and $C_{2}$, were isolated from this strain. Rubiginone $B_{1}$ was reported to potentiate the cytotoxicity of VCR by inhibiting VCR efflux [11]. Rubiginone $A_{2}$ and $B_{2}$ were also discovered from Streptomyces sp. SNA-8073 [12] and Saccharopolyspora sp. BCC 21906, respectively [13]. The Zeeck group isolated four new rubiginones, named rubiginone $D_{2}, H$, I and 4-O-acetyl-rubiginone $\mathrm{D}_{2}$, from Streptomyces sp. Gö N1/5 [14]. Hayakawa et al. isolated four new rubiginone analogues, including hatomarubigins $\mathrm{A}, \mathrm{B}, \mathrm{C}$, and D, from Streptomyces sp. 2238-SVT4. Rubiginone $\mathrm{B}_{2}$ was also isolated from Streptomyces sp. 2238-SVT4 and it was proposed to be a biosynthetic intermediate for the hatomarubigins [15].

Although the rubiginones have been identified for three decades and have been discovered from multiple actinomycetes, their biosynthetic gene clusters (BGCs) and biosynthetic pathways have not been characterized yet. In 2010, Kawasaki et al. characterized the $h r b$ gene cluster for hatomarubigin biosynthesis in Streptomyces sp. 2238SVT4, which consists of 30 open reading frames (ORFs) [16]. Heterologous expression of a part of the hrb gene cluster in Streptomyces lividans TK23 resulted in the production of hatomarubigins $\mathrm{A}, \mathrm{B}, \mathrm{C}$, and rubiginone $B_{2}$ [16]. In this study, we utilized the forward (from genes to metabolites) genome mining approach to characterize the two type II PKS BGCs in Streptomyces sp. CB02414 and correlated the $r u b$ gene cluster with the production of eight rubiginones, including five novel ones (rubiginones J, K, L, M, and N), from the CB02414 wild-type and gene-deletion mutants. Of the eight rubiginones, rubiginone J was identified as the final product of the rub gene cluster, and based on the structures of the isolated rubiginones, a biosynthetic pathway for the rubiginones was proposed.

\section{Results}

Bioinformatics analysis of the Streptomyces sp. CB02414 genome

Streptomyces sp. CB02414 was isolated from a soil sample collected on the beach of Dubai, United Arab Emirates. It was initially screened as a potential enediyne producer [17] and the presence of an enediyne BGC in the CB02414 genome (Accession number LIPF00000000.1) was confirmed by the antiSMASH analysis [18]. According to the antiSMASH result, CB02414 contains 27
BGCs, including three BGCs encoding nonribosomal peptides, six BGCs for terpenoids, three BGCs for siderophores and six BGCs for polyketides (Additional file 1: Table S1). Among the six polyketide BGCs, the two type II PKS gene clusters (cluster 5 and cluster 20) attracted our attention and were subjected to further bioinformatic analysis.

\section{Bioinformatics analysis of cluster 5 reveals a possible spore pigment BGC}

Analysis of cluster 5 revealed eight ORFs that encode proteins with high sequence similarities (identity $>66 \%$ ) to proteins from spore pigment BGCs, such as the whiE gene cluster from Streptomyces coelicolor A3(2) [19], the whiEa gene cluster from Streptomyces avermitilis [20], the cur gene cluster from Streptomyces curacoi [21], the sah gene cluster from Streptomyces sahachiroi ATCC 33158 [22], the mec gene cluster from Streptomyces bottropensis [23], the whiESa gene cluster from Streptomyces aureofaciens CCM3239 [24], and the $p k s A$ gene cluster from Streptomyces collinus DSM2012 (Accession number AF293354.1, unpublished data) (Fig. 1A). In addition to the high sequence similarity, cluster 5 displays identical gene organization to the whiE gene cluster. These results suggested that cluster 5 might be responsible for the biosynthesis of spore pigment in CB02414.

Cluster 20 displays high similarity with the $h r b$ gene cluster Annotation of cluster 20 (the rub cluster) revealed a 44-kbp DNA fragment consisting of 38 putative ORFs, and most of the encoded proteins showed high similarity with proteins from the $h r b$ gene cluster, which is responsible for the biosynthesis of the angucyclines hatomarubigins A, B, C, and D in Streptomyces sp. 2238-SVT4 [16] (Table 1). Therefore, we proposed that the rub gene cluster is responsible for the biosynthesis of natural products of the angucycline family.

The minimal PKS gene cassette (rubF1, rubF2, and $r u b F 3$ ) is located near the left boundary of the $r u b$ gene cluster. Interestingly, there is an $8.8-\mathrm{kbp}$ DNA region consisting of nine ORFs (rubM2 to rubP4) with identical organization to the fragment encoding proteins DWB77_01891 to DWB77_01899 from Streptomyces hundungensis (Fig. 2). The protein similarities between the nine ORFs from CB02414 and their respective homologues from $S$. hundungensis range from 45 to $80 \%$, and the DNA sequence identity between these two fragments is $78 \%$. AntiSMASH analysis of the S. hundungensis genome (Accession number CP032698.1) showed that the fragment containing proteins DWB77_1891 to DWB77_1899 is not located in a recognizable BGC. Moreover, the nine ORFs in the rub gene cluster do not exhibit similarities to proteins from the other known 


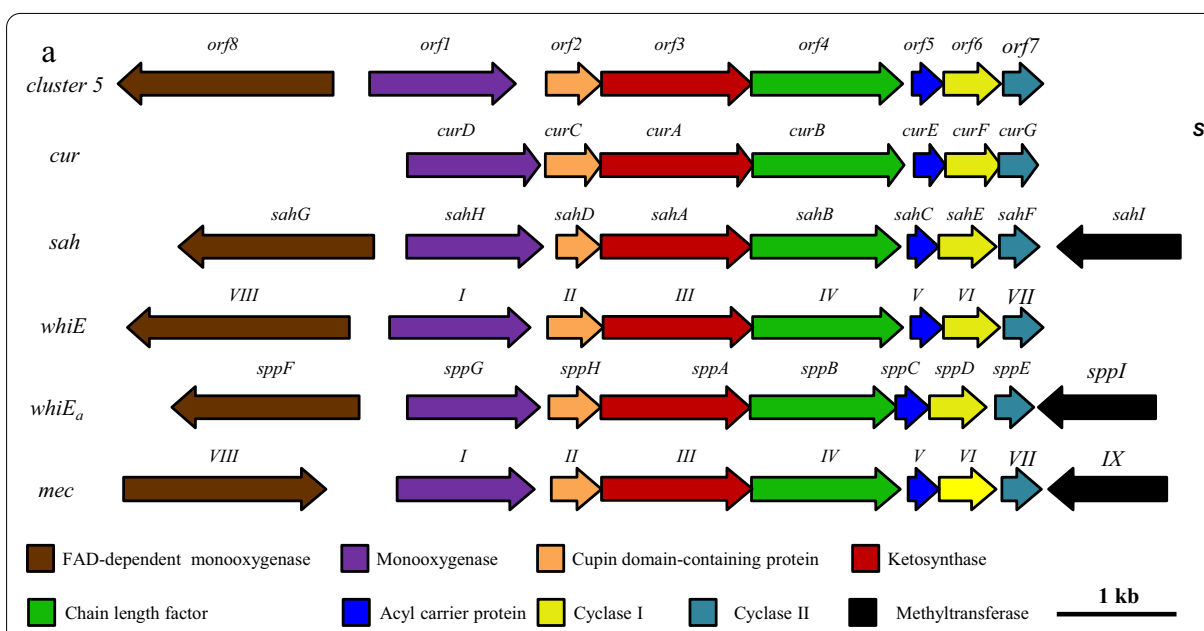

$\mathrm{b}$

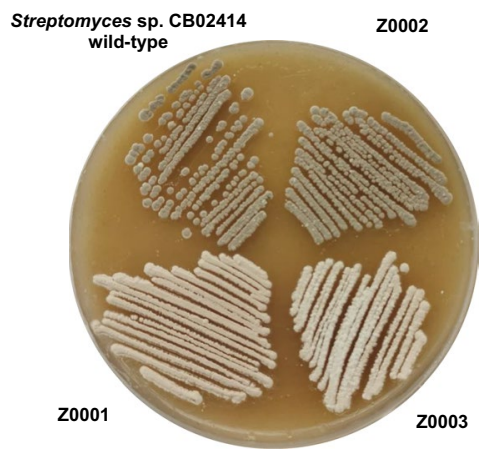

Fig. 1 Comparison of cluster 5 in Streptomyces sp. CB02414 with other BGCs for spore pigment biosynthesis (A), and spores of CB02414 (wild-type) and mutants Z0001-Z0003 on the GYM agar plate (B)

BGCs for angucycline or aromatic polyketide. Therefore, the 8.8-kbp DNA region in the rub gene cluster might arise from an insertion event caused by horizontal gene transfer or by transposition.

\section{Inactivation of the minimal PKSs in the two type II PKS gene clusters leading to different phenotypes}

To investigate the functions of the two type II PKS BGCs in CB02414, we inactivated orf3/orf4 (encoding ketosynthase and chain length factor, respectively) in cluster 5 , to generate the mutant strain Z0001, and rubF1/rubF2 to generate the mutant strain Z0002, respectively. In order to avoid the possible cross complementation between the two minimal PKS gene cassettes of cluster 5 and the rub cluster, we also constructed a double-deletion mutant Z0003, in which the genes encoding the two ketosynthases and the two chain length factors in cluster 5 and the $r u b$ cluster were inactivated together (Additional file 1: Fig. S1).

The CB02414 wild-type and the Z0002 mutant strains produced grey pigmentation on the GYM agar plate, while the color of the spores of Z0001 and Z0003 was pale yellow on the same plate (Fig. 1B). Comparison of the HPLC profiles of the CB02414 wild-type and the Z0001 mutant did not reveal noticeable difference, while most of the peaks at $254 \mathrm{~nm}$ (compounds 1-8) disappeared in Z0002 and Z0003 (Fig. 3). These results clearly demonstrated that cluster 5 is involved in the formation of spore pigment in CB02414, and the rub gene cluster is responsible for the biosynthesis of compounds 1-8.

\section{Large-scale fermentation and structural elucidation} of the rubiginones from the $\mathrm{CB} 02414$ wild-type strain The CB02414 wild-type strain was cultivated in three different media (medium B, C, and F), and the abundances of compounds 1-8 in these media were analyzed. Medium $\mathrm{C}$ was selected for large-scale fermentation because of the highest titers for compounds 1-8. (Additional file 1: Fig. S2). Eight rubiginone analogues were isolated and characterized from an 8-L fermentation of the CB02414 wild-type strain, including five new compounds (compounds 1, 2, 5, 7, and 8) whose structures were established by extensive spectral analysis (Fig. 4). The five new compounds were named rubiginones $\mathrm{J}$ (1), K (2), L (5), M (7), and N (8), respectively (Fig. 5). Rubiginones $\mathrm{K}$ and $\mathrm{L}$ are different from other known rubiginones, because their $\mathrm{C}-1$ and $\mathrm{C}-12$ positions have hydroxyl groups instead of carbonyl groups found in other rubiginones. The identities of rubiginone $B_{2}(3)$ [10], rubiginone $\mathrm{A}_{2}$ (4) [10], and ochromycinone (6) [25] were determined by comparing their individual ${ }^{1} \mathrm{H}$ and ${ }^{13} \mathrm{C}$ NMR data with the NMR data from literature (Additional file 1: Figs. S3-S8). The C-3 methyl group in compounds 3, 4, and 6 has a $\beta$-configuration. Because this configuration arises from the early cyclization step of the angucycline skeleton biosynthesis, it is reasonable to speculate that the C-3 methyl group of all the rubiginones from CB02414 adopts a $\beta$-configuration. The peak marked with asterisk (Fig. 3) has different UV spectra from compound 1, but it was converted quickly to compound $1(<1 \mathrm{~h})$ during the isolation and purification steps, and we were not able to determine its structure (Additional file 1: Fig. S9).

Rubiginone $\mathrm{J}$ (1) was obtained as light-yellow needles. Its molecular formula $\mathrm{C}_{20} \mathrm{H}_{16} \mathrm{O}_{6}$ was established 
Table 1 Proposed functions of proteins of the rub BGC in Streptomyces sp. CB02414

\begin{tabular}{|c|c|c|c|c|}
\hline \multirow[t]{2}{*}{ Protein } & \multirow[t]{2}{*}{ Size (aa) } & \multirow[t]{2}{*}{ Proposed function } & \multicolumn{2}{|l|}{ Homologs } \\
\hline & & & Protein/organism & $\begin{array}{l}\text { Accession no. } \\
\text { (similarity/identity } \\
\%)\end{array}$ \\
\hline $\operatorname{Rub}(-1)$ & 258 & AfsR/SARP family regulator & MoaR2/Streptomyces sp. S4.7 & QHY99565.1 (54/68) \\
\hline RubA1 & 237 & Regulator & $\mathrm{HrbR3}$ & BAJ07866.1 (54/66) \\
\hline RubB1 & 235 & Oxidoreductase & HrbS & BAJ07858.1 (48/61) \\
\hline RubC & 279 & Type II toxin-antitoxin chaperone & HigA/Pseudomonas fluorescens F113 & AEV65067.1 (51/65) \\
\hline RubD1 & 489 & Oxygenase & $\mathrm{HrbR}$ & BAJ07857.1 (70/78) \\
\hline RubE & 108 & Cyclase & HrbB & BAJ07841.1 (70/78) \\
\hline RubF1 & 424 & Ketosynthase $\left(\mathrm{KS}_{\alpha}\right)$ & $\mathrm{HrbC}$ & BAJ07842.1 (80/89) \\
\hline RubF2 & 406 & Chain length factor $\left(\mathrm{KS}_{\beta}\right)$ & HrbE & BAJ07844.1 (69/80) \\
\hline RubF3 & 85 & Acyl carrier protein & HrbM & BAJ07852.1 (59/67) \\
\hline RubG & 261 & Ketoreductase & $\mathrm{HrbO}$ & BAJ07854.1 (80/87) \\
\hline RubH & 361 & Aromatase & HrbP & BAJ07855.1 (67/79) \\
\hline Rubl1 & 678 & Hydroxylase & HrbG & BAJ07846.1 (68/78) \\
\hline RubB2 & 256 & Oxidoreductase & HrbS & BAJ07858.1 (71/81) \\
\hline RubJ & 522 & Decarboxylase & JadN/Streptomyces venezuelae & AAK01934.1 (86/92) \\
\hline RubK & 71 & Acyl-CoA carboxylase subunit & C7987_1162/Streptomyces venezuelae & PWW46500.1 (69/77) \\
\hline RubD2 & 322 & Oxygenase & $\mathrm{HrbH}$ & BAJ07847.1 (77/85) \\
\hline RubL & 414 & Transporter & HrbT & BAJ07859.1 (59/70) \\
\hline Rubl2 & 206 & Hydroxylase & $\mathrm{HrbW}$ & BAJ07862.1 (52/68) \\
\hline RubD3 & 221 & Antibiotic biosynthesis monooxygenase & ADL21_13530/Streptomyces albus & KWT61349.1 (36/49) \\
\hline RubM1 & 228 & Methyltransferase & $\mathrm{HrbF}$ & BAJ07845.1 (44/58) \\
\hline RubA2 & 201 & TetR family regulator & Betl/Streptomyces sp. Go-475 & AXE89736.1 (76/84) \\
\hline RubB3 & 275 & Oxidoreductase & HrbS & BAJ07858.1 (24/41) \\
\hline RubN1 & 404 & Cytochrome P450 & NcmG/Saccharothrix syringae & ARS01480.1 (54/66) \\
\hline RubM2 & 288 & Methyltransferase & DWB77_01891 & AYG79773.1 (48/58) \\
\hline RubO & 260 & Alpha/beta hydrolase & DWB77_01892 & AYG79774.1 (47/64) \\
\hline RubA3 & 212 & Lys family regulator & DWB77_01893 & AYG79775.1 (58/69) \\
\hline RubP1 & 254 & Hypothetical protein & DWB77_01894 & AYG79776.1 (59/71) \\
\hline RubP2 & 373 & Hypothetical protein & DWB77_01895 & AYG79777.1 (70/78) \\
\hline RubB4 & 488 & Oxidoreductase & DWB77_01896 & AYG79778.1 (57/65) \\
\hline RubM3 & 291 & Methyltransferase & DWB77_01897 & AYG79779.1 (80/88) \\
\hline RubP3 & 567 & GH3 auxin-responsive promoter & DWB77_01898 & AYG79780.1 (45/59) \\
\hline RubP4 & 209 & Hypothetical protein & DWB77_01899 & AYG79781.1 (66/77) \\
\hline RubQ & 431 & Acyltransferase & PauY24/Streptomyces sp. YN86 & AlE54244.1 (44/57) \\
\hline RubR & 71 & Ferredoxin & HbmFdx/Streptomyces hygroscopicus & AAY28236.1 (50/62) \\
\hline RubN2 & 403 & Cytochrome P450 & SceD/Streptomyces sp. SD85 & ANH11399.1 (47/63) \\
\hline RubA4 & 225 & TetR regulatory protein & AbmC/Streptomyces koyangensis & AVI57423.1 (50/62) \\
\hline RubL2 & 493 & MFS transporter & AbmD/Streptomyces koyangensis & AVI57425.1 (46/65) \\
\hline RubM4 & 345 & O-Methyltransferase & $\mathrm{HrbU}$ & BAJ07860.1 (60/74) \\
\hline Rubs & 585 & Acetyl-/propionyl-CoA carboxylase subunit alpha & JadJ/Streptomyces venezuelae & AAD37851.1 (86/91) \\
\hline $\operatorname{Rub}(+1)$ & 407 & Methionine adenosyltransferase & SLA_0973/Streptomyces laurentii & BAU81924.1 (92/95) \\
\hline
\end{tabular}

${ }^{a}$ The $h r b$ homologous proteins are from Streptomyces sp. 2238-SVT4

${ }^{\mathrm{b}}$ The DWB77_01891 to DWB77_01899 proteins are from Streptomyces hundungensis

upon analysis of the HR-ESI-MS peak at $\mathrm{m} / z 353.1022$ $[\mathrm{M}+\mathrm{H}]^{+}$(calculated for the $[\mathrm{M}+\mathrm{H}]^{+}$ion at 353.1020) (Additional file 1: Fig. S10). Rubiginone J has the same molecular formula as rubiginone $\mathrm{D}_{2}$, but the NMR data and NOESY correlation indicted that the C-4 hydroxyl group of the former compound has an $\alpha$-configuration, 


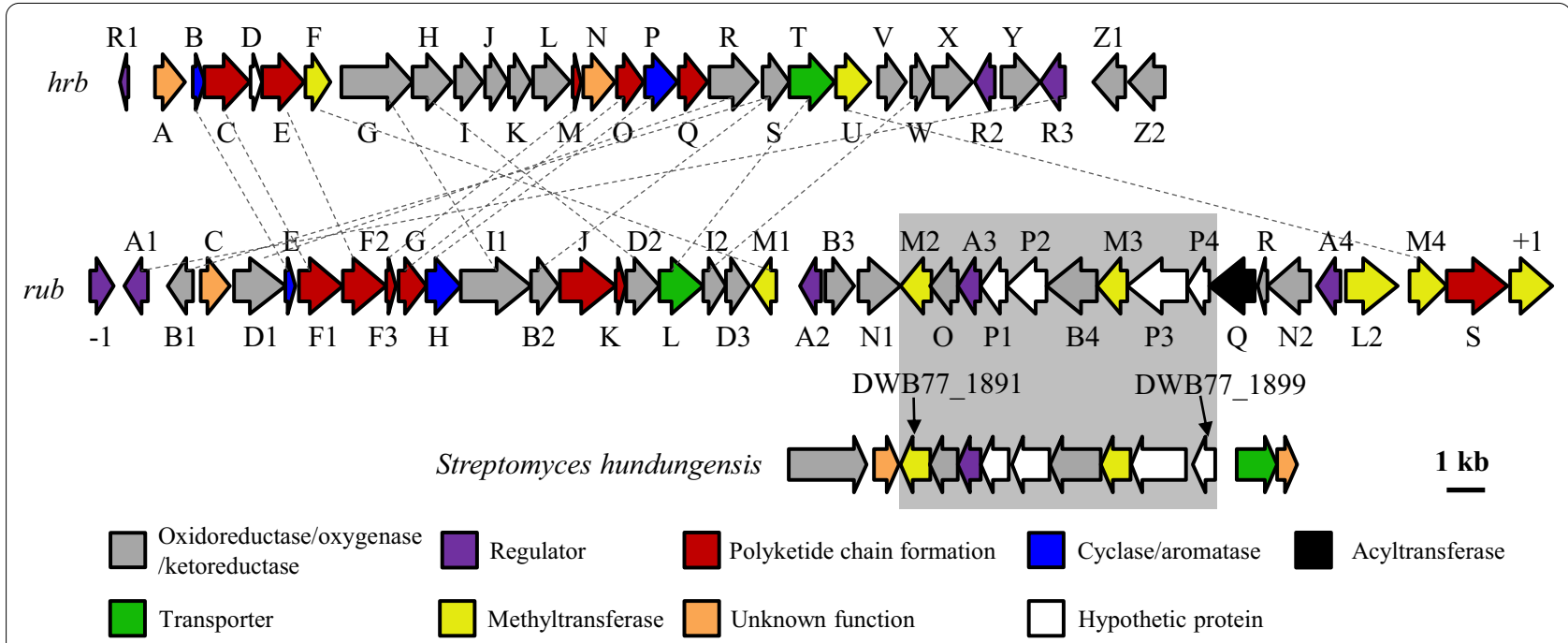

Fig. 2 The organization of the rub gene cluster in Streptomyces sp. CB02414

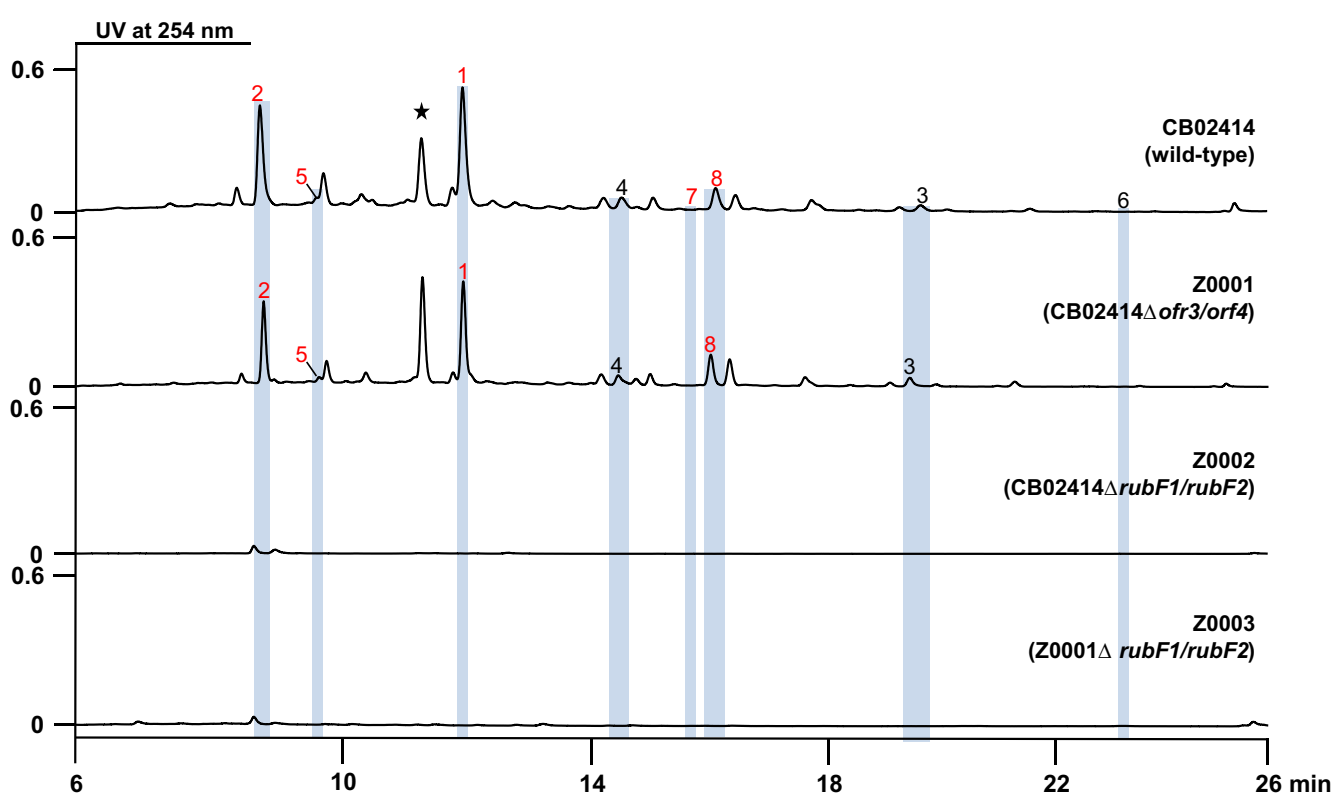

Fig. 3 HPLC analysis of the rubiginone production in Streptomyces sp. CB02414 (wild-type) and the Z0001-Z0003 mutants

while that of the latter compound has a $\beta$-configuration. The relative structure of compound $\mathbf{1}$ was determined by the ${ }^{1} \mathrm{H}-{ }^{1} \mathrm{H}$ COSY, HSQC and HMBC data (Additional file 1: Figs. S11-S17; Table S2). The absolute configuration of compound 1 was further supported by circular dichroism (CD) and electronic circular dichroism (ECD) analysis (Fig. 5c; Additional file 1: Figs. S18-S21).

Rubiginone $\mathrm{K}$ (2) was obtained as brown oil. The molecular formula $\mathrm{C}_{20} \mathrm{H}_{20} \mathrm{O}_{6}$ was established upon analysis of the HR-ESI-MS peak at $m / z$ 357.1334 $[\mathrm{M}+\mathrm{H}]^{+}$ (calculated for $[\mathrm{M}+\mathrm{H}]^{+}$ion at 357.1333) (Additional file 1: Fig. S10). The UV absorption of rubiginone $\mathrm{K}$ was significantly different from rubiginone J (1) (Additional file 1: Fig. S22). The ${ }^{13} \mathrm{C}-\mathrm{NMR}$ data showed that compound 2 possesses two hydroxyl groups at $\mathrm{C}-7$ and $\mathrm{C}-12$, which is different from the two carbonyl groups at $\mathrm{C}-7$ and $\mathrm{C}-12$ in compound $\mathbf{1}$. The absolute structure of rubiginone $\mathrm{K}$ was determined by ${ }^{1} \mathrm{H}-{ }^{1} \mathrm{H}$ COSY, $\mathrm{HSQC}$, HMBC and NOESY analysis, as well as the X-ray Crystal 
<smiles>COc1cccc2c1C(=O)c1ccc3c(c1C2=O)C(=O)[C@H](O)[C@@H](C)[C@H]3O</smiles>

Rubiginone J (1)<smiles>COc1cccc2c1C(=O)c1ccc3c(c1[C@H]2O)[C@H](O)C[C@@H](C)[C@H]3O</smiles>

Rubiginone L (5)<smiles>COc1cccc2c1C(=O)c1ccc3c(c1[C@H]2O)[C@H](O)[C@H](O)[C@H](C)[C@H]3O</smiles>

Rubiginone K (2)<smiles>C[C@H]1CC(=O)c2c(ccc3c2C(=O)c2cccc(O)c2C3=O)C1</smiles>

Ochromycinone (6)<smiles>COc1cccc2c1C(=O)c1ccc3c(c1C2=O)C(=O)C[C@@H](C)C3</smiles>

Rubiginone $\mathrm{B}_{2}(\mathbf{3})$<smiles>COc1cccc2c1C(=O)c1ccc3c(c1C2=O)C(=O)[C@H](O)[C@@H](C)C3</smiles>

Rubiginone M (7)<smiles>COc1cccc2c1C(=O)c1ccc3c(c1C2=O)C(=O)C[C@@H](C)[C@H]3O</smiles>

Rubiginone $A_{2}(4)$<smiles>COc1cccc2c1C(=O)c1ccc3c(c1C2=O)C(=O)[C@H](O)[C@@H](C)[C@H]3OC(C)=O</smiles>

Rubiginone N (8)

Fig. 4 Rubiginones isolated from Streptomyces sp. CB02414

diffraction (CDCC Deposit number: 2093018) analysis (Fig. 5b; Additional file 1: Figs. S23-S29; Tables S3, S4).

Rubiginone L (5) was obtained as brownish-red oil. Its molecular formula $\mathrm{C}_{20} \mathrm{H}_{20} \mathrm{O}_{5}$ was established upon analysis of the HR-ESI-MS peak at $m / z 341.1390$ $[\mathrm{M}+\mathrm{H}]^{+}\left(\right.$calculated for $[\mathrm{M}+\mathrm{H}]^{+}$ion at 341.1384) (Additional file 1: Fig. S30). The UV spectrum of rubiginone L (Additional file 1: Fig. S22) is similar to rubiginone K. Compared to rubiginone $\mathrm{K}$, rubiginone $\mathrm{L}$ lacks the $\mathrm{C}-2$ hydroxyl group. The structure of rubiginone $\mathrm{L}$ was determined by ${ }^{1} \mathrm{H}-{ }^{1} \mathrm{H}$ COSY, HSQC and $\mathrm{HMBC}$, as well as the X-ray Crystal diffraction (CDCC Deposit number: 2093031) analysis (Fig. 5b; Additional file 1: Figs. S31S36; Tables S5, S6).

Rubiginone M (7) was obtained as brown powder. The molecular formula $\mathrm{C}_{20} \mathrm{H}_{16} \mathrm{O}_{5}$, was established upon analysis of the HR-ESI-MS peak at $m / z 337.1072[\mathrm{M}+\mathrm{H}]^{+}$ (calculated for $[\mathrm{M}+\mathrm{H}]^{+}$ion at 337.1071) (Additional file 1: Fig. S30). The molecular formula of rubiginone $M$ is the same as compound 4 . However, from the ${ }^{1} \mathrm{H},{ }^{13} \mathrm{C}$ NMR and 2D-NMR data (Additional file 1: Figs. S37S43), it is clear that rubiginone $M$ has a hydroxyl group at $\mathrm{C}-2\left(\delta_{\mathrm{H}} 4.84 ; \delta_{\mathrm{C}} 78.22\right)$ position, while in compound 4 the hydroxyl group is at the $\mathrm{C}-4$. The $(2 S, 3 S)$ configuration of rubiginone $M$ was supported by the $C D$ and ECD analysis (Fig. 5c; Additional file 1: Figs. S44-S45).

Rubiginone $\mathrm{N}(\mathbf{8})$ was obtained as brown powder. The molecular formula $\mathrm{C}_{22} \mathrm{H}_{18} \mathrm{O}_{7}$ was established upon analysis of the HR-ESI-MS peak at $m / z 395.1132[\mathrm{M}+\mathrm{H}]^{+}$ (calculated for $[\mathrm{M}+\mathrm{H}]^{+}$ion at 395.1125) (Additional file 1: Fig. S30). Rubiginone $\mathrm{N}$ has the same molecular formula as the known compound 4-O-acetyl-rubiginone $\mathrm{D}_{2}$ [14]. According to the NOESY spectrum (Additional file 1: Fig. S52), the hydrogen atom on $\mathrm{C}-3$ of rubiginone $\mathrm{N}$ has correlation with the hydrogen atom at $\mathrm{C}-4$, indicating that the hydroxyl group at $\mathrm{C}-4$ of rubiginone $\mathrm{N}$ has an $\alpha$ configuration, while $4-O$-acetyl-rubiginone $\mathrm{D}_{2}$ possesses a $\beta$ configuration at $C-4$. The absolute structure of rubiginone $\mathrm{N}$ was further determined by ${ }^{1} \mathrm{H}-{ }^{1} \mathrm{H}$ COSY, HSQC and HMBC analysis (Additional file 1: Figs. S46$\mathrm{S} 51$ ). Rubiginone $\mathrm{N}$ is an acetylation derivative of rubiginone J.

\section{Characterization of the two cytochrome P450 hydroxylases and the $\mathbf{O}$-methyltransferase}

The two cytochrome P450 hydroxylase-encoding genes, rubN1 and rubN2, and the gene encoding a putative $O$-methyltransferase, rubM4, were individually inactivated by in-frame deletion [26], to generate mutant strains Z0004 (i.e., CB02414 $\Delta r u b N 1)$, Z0005 (i.e., CB02414 $\Delta r u b N 2)$, and Z0008 (i.e., CB02414 $\Delta r u b M 4$ ) (Additional file 1: Fig. S53). The respective genes were cloned into the pSET152 plasmid under the ermE $E^{*}$ promoter and introduced into the respective gene-deletion mutants for complementation, to generate mutant strains Z0006 (for rubN1 complementation), Z0007 (for rubN2 complementation), and Z0009 (for rubM4 complementation).

The Z0004 mutant produced compounds 3, 4, 5, and 6 , and the production of compounds $1,2,7$, and 8 was abolished. All the produced compounds in Z0004 lack the hydroxyl group at C-2, but compounds $\mathbf{4}$ and 5 still possess the C-4 hydroxyl group. When rubN1 was introduced into Z0004, production of all the eight rubiginones was restored in the complementation strain Z0006. These results suggested that RubN1 


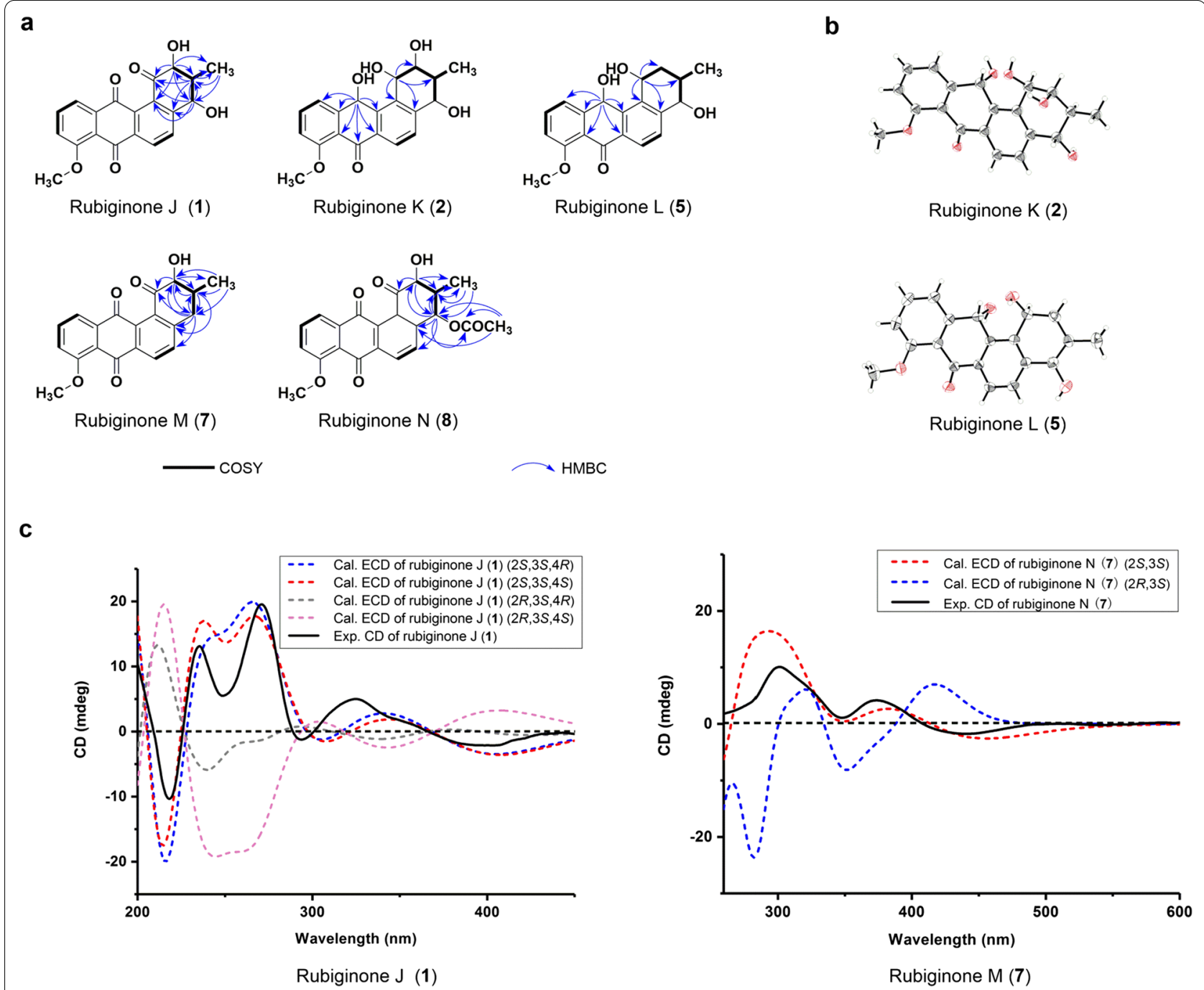

Fig. 5 Structure elucidation of compounds 1, 2, 5, $\mathbf{7}$ and $\mathbf{8}$. a COSY and HMBC correlations of compounds 1, 2, 5, 7 and 8. b The X-ray Crystallographic study of compounds $\mathbf{2}$ and $\mathbf{5}$ (30\% probability displacement ellipsoids). c The CD spectra of compounds $\mathbf{1}$ and $\mathbf{7}$

is responsible for the introduction of the $\beta$-hydroxyl group at C-2. Similarly, the Z0005 mutant only produced compounds 3, 6, and 7, which lack the C-4 hydroxyl group, and the production of the other five compounds (rubiginones J, $\mathrm{K}, \mathrm{A}_{2}, \mathrm{~L}$, and $\mathrm{N}$ ) that have the C-4 hydroxyl group was abolished. The rubN2 complementation strain Z0007 was able to produce all the eight rubiginones. Therefore, RubN2 catalyzes the C-4 oxidation step to form a hydroxyl group with an $\alpha$-configuration (Fig. 6).

The rubM4-deletion mutant Z0008 only produced compound 6 which contains a C-8 hydroxyl group instead of the C-8 methoxy group in the other seven compounds. In the rubM4 complementation strain Z0009, production of all the eight rubiginones was restored. From these results, it is clear that RubM4 is responsible for the methylation of the C-8 hydroxyl group in compound $\mathbf{6}$. Since compound $\mathbf{6}$ is the only rubiginone product of $\mathrm{Z} 0008$, the $\mathrm{C}-8$ methylation reaction should occur in the early stage of the post-PKS tailoring steps in rubiginone biosynthesis (Fig. 6).

\section{Proposed biosynthetic pathway for the rubiginones in CB02414}

Thanks to the early biosynthetic studies on typical angucyclines, exemplified by urdamycin, landomycin, simocyclinone, and jadomycin, biosynthesis of the benz $[a]$ anthracene skeleton was well elucidated [9]. The post-PKS tailoring reactions are the major factors that generate the structural diversity of angucyclines. 


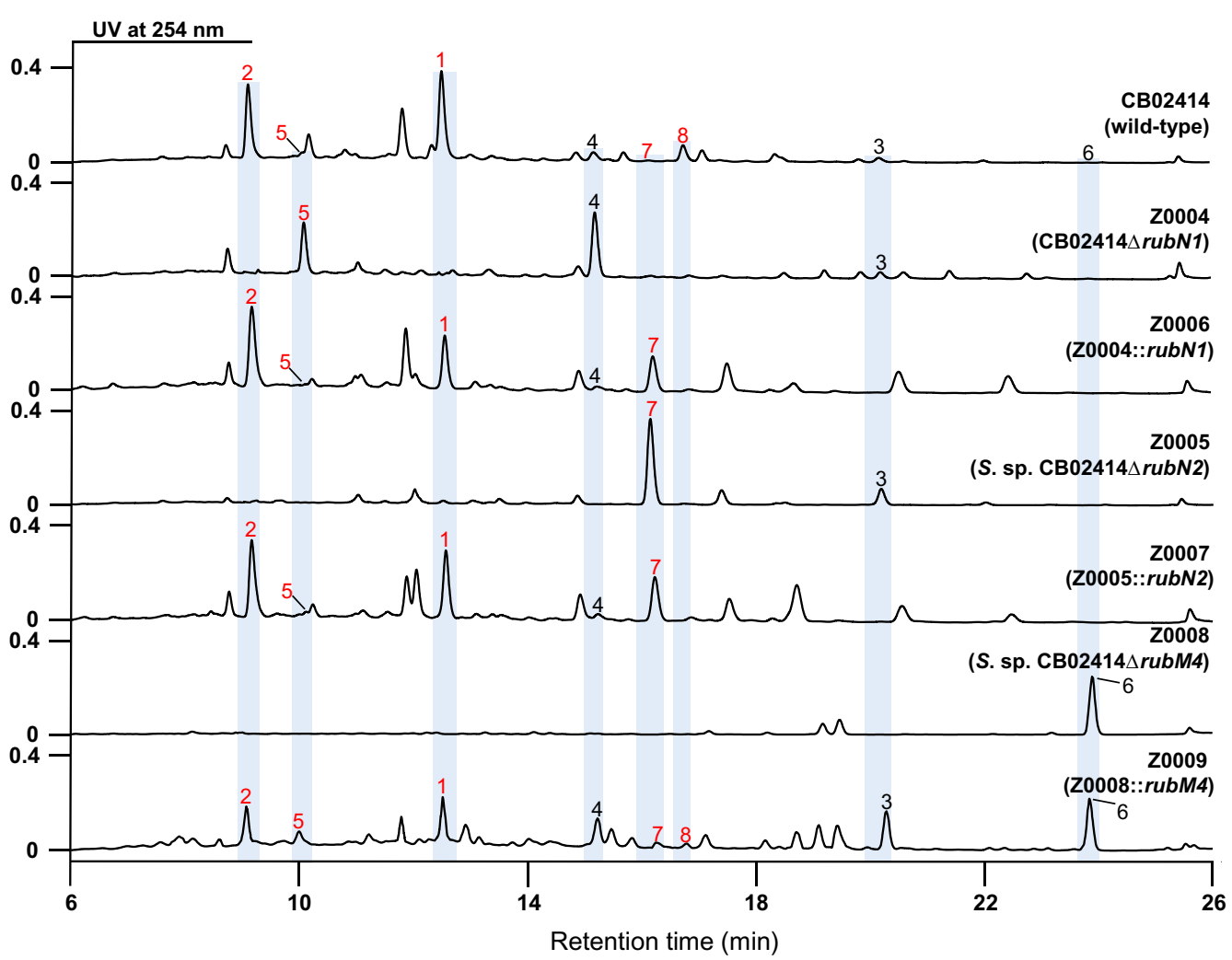

Fig. 6 HPLC analysis of rubiginone production in Streptomyces sp. CB02414 (wild-type) and the Z0004-Z0007 mutants

In the rub gene cluster of CB02414, the presence of two cytochrome $\mathrm{P} 450$ hydroxylases and one $\mathrm{O}$-methyltransferase was key to understanding the biosynthesis of the rubiginones. Based on the structures of the eight rubiginones isolated from the CB02414 wild-type and mutants, we proposed a biosynthetic pathway for these compounds (Fig. 7).

The four proteins RubF1, RubF2, RubF3, and RubG, which represent ketoacyl synthase, chain length factor, acyl carrier protein, and a PKS-associated ketoreductase, respectively, are common in all aromatic polyketide BGCs. The aromatase RubH and cyclase RubE are homologous to other counterparts in type II PKS gene clusters [9]. It was proposed that the six proteins mentioned above are sufficient to produce UWM6, the common biosynthetic intermediate for angucyclines [9] After a few modification steps, UWM6 is converted to ochromycinone (6), the earliest intermediate isolated in this study. The methyltransferase RubM4 catalyzes the methylation of C-8 hydroxyl group to form rubiginone $B_{2}$ (3), which is used as a substrate by the cytochrome P450 hydroxylases RubN1 and RubN2, to generate rubiginone J. There are two possible pathways for the two P450-catalyzed conversions from rubiginone $B_{2}$ to rubiginone J: (i) in path a, RubN1 catalyzes the $\mathrm{C}-2$ hydroxylation to form rubiginone $\mathrm{M}$, which is used as a substrate by RubN2 to introduce the $C$ - $4 \beta$-hydroxyl group to produce rubiginone J; (ii) in path $b$, rubiginone $B_{2}$ is oxidized by RubN2 to generate compound 4, followed by the RubN1catalyzed transformation of compound 4 to rubiginone J. From the production profiles of the CB02414 wildtype and mutant strains, it seems that both path a and path b are applicable in CB02414 (Fig. 7). Compound 8 is an acetyl derivative of compound $\mathbf{1}$, and it is a minor product of the CB02414 wild-type strain. It is not clear whether the acetylation of compound $\mathbf{1}$ is a spontaneous or an enzymatic reaction.

\section{Discussion}

Actinobacteria are a rich resource of bioactive natural products, many of which have been extensively used in the clinical setting. However, most of the antibiotics used today were discovered 50 years ago and the rapid emergence of antibiotic resistance requires the discovery of new natural products with novel mode of action. Recent advances in high-throughput strain prioritization [17], next generation genome sequencing, and bioinformatics analysis [18, 27-30] have disclosed that actinobacteria possess a huge potential in producing novel secondary 


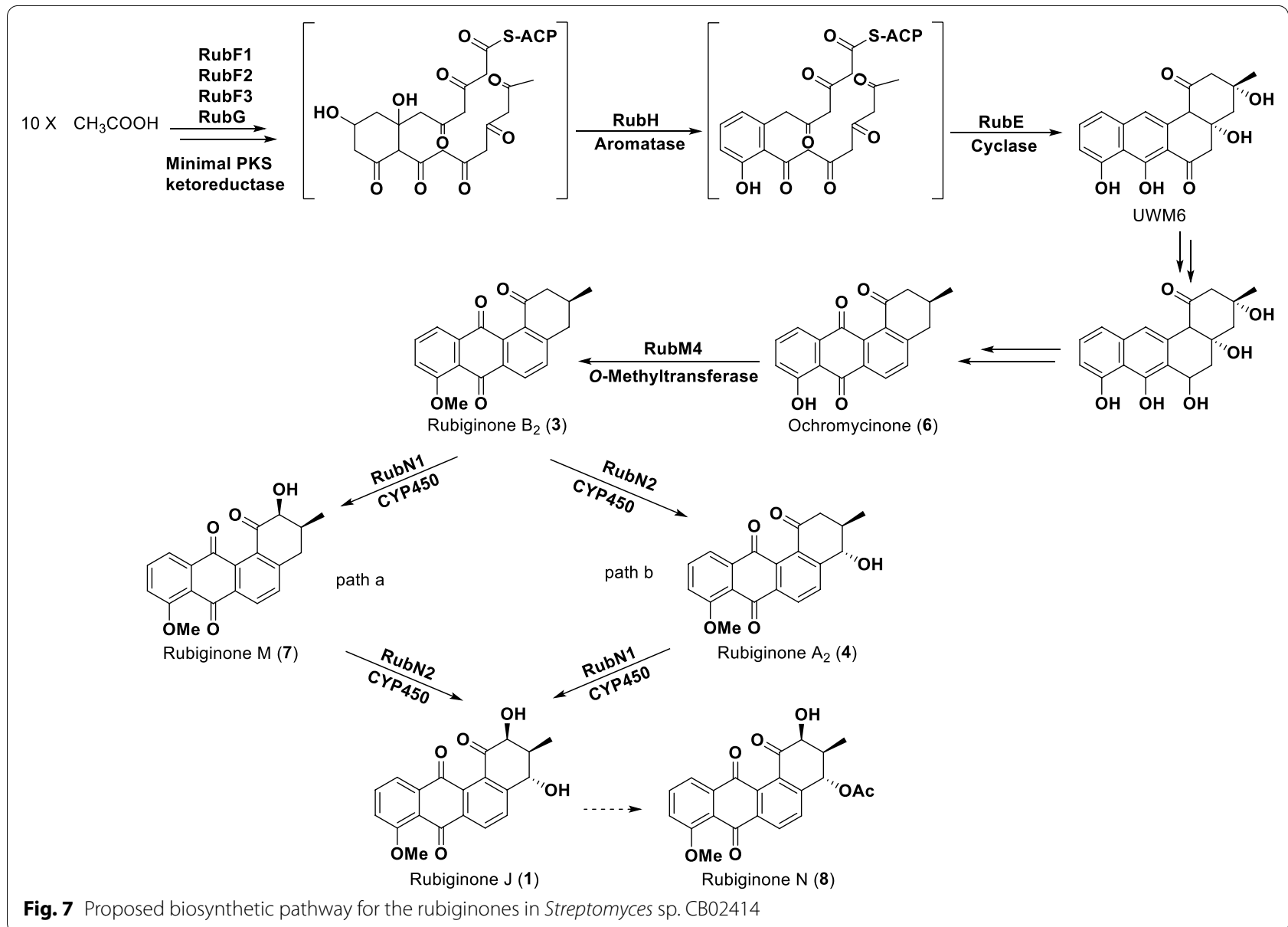

metabolites. Most of the BGCs in actinobacteria are silent under routine laboratory fermentation conditions. Therefore, linking BGCs to their encoded natural products (also known as the forward genome mining approach) is an important step in the discovery of novel microbial natural products. Many natural products have been identified by using the forward genome mining strategy [31].

Angucyclines have broad biological activities, including antitumor, antimicrobial, enzyme inhibition. Therefore, their discovery and understanding their structure-activity relationship has been a focus of natural product chemists. Although hundreds of members have been characterized in the past 60 years, the number of angucyclines is still growing quickly. According to our recent survey, more than 200 novel angucycline natural products have been reported in the last decade, most of which are isolated from Streptomyces spp. Biosynthetic studies of angucyclines are always intriguing, because of the diverse modifications brought by the post-PKS tailoring enzymes, such as oxidoreductases and glycosyltransferases [32, 33]. Compared with the complex oxidative rearrangement reactions and decorations, biosynthesis of the angucycline backbones is proposed to occur via two different biosynthetic routes, using the benz $[a]$ anthracene intermediate and the anthracyclinone intermediate, respectively. The benz $[a]$ anthracene intermediate is involved in the formation of landomycin A, chrysomycin A, ravidomycin $\mathrm{V}$, and kinamycin $\mathrm{D}$ [9]. The anthracycline intermediate was observed in the biosynthesis of angucyclines PD116198 and BE7585A [9].

More than ten rubiginones have been isolated from S. griseorubiginosus Q144-2, Saccharopolyspora sp. BCC 21906, Streptomyces sp. Gö N1/5, Streptomyces sp. SNA-8073, and Streptomyces sp. KMC004. Besides the well-known biological activities for angucyclines, such as cytotoxicity, antibacterial, and platelet aggregation inhibition, the rubiginones are able to potentiate the cytotoxicity of vincristine (VCR) against VCR-resistant cancer cell lines. Although many rubiginones have been isolated to date, their BGCs and biosynthetic pathways were not reported. The $h r b$ gene cluster was cloned and characterized in 2010 and the biosynthetic pathway for hatomarubigins was proposed. However, the post-PKS 
modifications of the hatomarubigins occur mainly on the D-ring. In this study, we analyzed the genome of Streptomyces sp. CB02414 and characterized the rub gene cluster that is responsible for the biosynthesis of the eight rubiginones isolated from CB02414. The rubiginones isolated from CB02414 feature different oxidative modifications on the A-ring. Based on the rubiginones produced by the CB02414 wild-type and mutant strains, we were able to propose a plausible biosynthetic pathway for the rubiginones. In this pathway, the two cytochrome P450 hydroxylases RubN1 and RubN2 introduce the $\alpha$-hydroxyl group at $\mathrm{C}-2$ and the $\beta$-hydroxyl group at $\mathrm{C}-4$, respectively. Our attempts to overexpress rubN1 and rubN2 in Escherichia coli BL21 (DE3) failed to produce soluble proteins, thus hindering the kinetics studies of these two enzymes. We also introduced rubN1 and rubN2 into different Streptomyces hosts, including Streptomyces lividans TK24 and Streptomyces albus J1074, and tried the biotransformation of compound $\mathbf{3}, \mathbf{4}$, and 7 in the resulted strains, but no conversion was observed (data not shown). It is possible that the fed rubiginones was not able to penetrate the cell membrane of the heterologous hosts, and the biotransformation could not occur without the substrates.

It is interesting that we were able to obtain the crystals for rubiginones $\mathrm{K}$ and $\mathrm{L}$, which helped us to establish the configurations of the hydroxyl groups or methyl group at the $\mathrm{C}-2, \mathrm{C}-3$, and $\mathrm{C}-4$ of the isolated rubiginones. We also conducted crystallization of the other isolated rubiginones using different conditions, but no crystal was obtained. Considering that rubiginones $\mathrm{K}$ and $\mathrm{L}$ both possess hydroxyl groups at $\mathrm{C}-1$ and $\mathrm{C}-12$, this structural feature may facilitate the crystallization process. Rubiginones $\mathrm{K}$ and $\mathrm{L}$ are not stable and their $\mathrm{C}-1$ and C-12 hydroxyl groups are oxidized into ketones during the purification procedure, to generate rubiginones $\mathrm{J}$ and $\mathrm{A}_{2}$, respectively. The photo-induced oxidation of $\mathrm{C}-1$ hydroxyl group in rubiginones was reported before [34], we believed that the oxidation of $\mathrm{C}-12$ hydroxyl group may follow a similar mechanism as the $\mathrm{C}-1$ hydroxyl group. Rubiginone $\mathrm{K}$ was produced as a major metabolite in the CB02414 wild-type and rubiginone $L$ was a major product of the Z0004 mutant, but it remains unclear how these two rubiginones are biosynthesized and whether they are shunt products of the rubiginone biosynthetic pathway.

\section{Conclusions}

In this study, we first analyzed the two type II PKS gene clusters in Streptomyces sp. CB02414 and identified their functions through gene-inactivation experiments. We isolated eight rubiginones, including five new ones, from the CB02414 wild-type strain. Their structures were determined by the combination of HR-ESI-MS, $1 \mathrm{D}$ and 2D NMR, X-ray crystal diffraction, CD test, and ECD calculations. We investigated the functions of two cytochrome P450 hydroxylases (RubN1 and RubN2) in the rub cluster of CB02414 and confirmed that they are responsible for the introduction of the hydroxyl groups at $\mathrm{C}-2$ and $\mathrm{C}-4$ of rubiginones, respectively. Based on the production profiles in the CB02414 wild-type and the gene-deletion mutant strains, we proposed a biosynthetic pathway for the rubiginones. Our study enlarges the rubiginone family of natural products and lays the foundation for the generation of novel rubiginones using the combinatory biosynthesis strategy. Moreover, this study exemplifies the power of the genome mining strategy in the targeted discovery of novel microbial natural products.

\section{Methods}

\section{General experimental procedures}

HRMS spectra were analyzed on an LTQ-ORBITRAPETD instrument (Thermo Scientific, MA, USA). NMR spectra were recorded on the Varian spectrometers (400/500/600 MHz) (Brucker, Ettlingen, Germany). CD spectroscopy was measured by using JASCO (J-185, Tokyo, Japan) at room temperature $\left(25^{\circ} \mathrm{C}\right)$. Crystal data using $\mathrm{Cu} \mathrm{K} \alpha$ radiation were acquired on a Rigaku APEXII XtaLAB PRO MM007HF diffractometer at $100 \mathrm{~K}$. Optical Rotatory Dispersion (ORD) spectrum was used to determine the optical activity of compounds (Rudolph Research Analytical, Autopol IV, USA). For purification of compounds, column chromatography (CC) was carried out using silica gel or Sephadex LH-20. Reversedphase high performance liquid chromatography (RP-HPLC) was performed using a Waters 1525 Binary HPLC Pump equipped with a Welch Ultimate AQ-C18 column $(250 \times 10 \mathrm{~mm}, 5 \mu \mathrm{m}$, Welch Materials Inc., Shanghai, China) and a Waters 2489 UV/Visible Detector (Shimadzu, Kyoto, Japan).

\section{Bacterial strains and fermentation}

Streptomyces sp. CB02414 was grown on the GYM agar plate containing per liter: $4 \mathrm{~g}$ yeast extract, $4 \mathrm{~g}$ glucose, $10 \mathrm{~g}$ malt extract, $2 \mathrm{~g} \mathrm{CaCO}_{3}, 20 \mathrm{~g}$ agar, $\mathrm{pH}$ 7.2) and incubated at $30{ }^{\circ} \mathrm{C}$ to obtain spores after $3-5$ days. Escherichia coli DH $5 \alpha$ and S17-1 were grown in liquid Luria-Bertani medium with antibiotic added (apramycin or kanamycin) and incubated at $30{ }^{\circ} \mathrm{C}$ for $12 \mathrm{~h}$. The final concentration of antibiotic was $50 \mu \mathrm{g} / \mathrm{mL}$.

Streptomyces sp. CB02414 was inoculated into $250-\mathrm{mL}$ Erlenmeyer flasks containing $50 \mathrm{~mL}$ tryptic soy broth (TSB) medium and some glass beads, then cultivated at $30{ }^{\circ} \mathrm{C}$ on a rotary shaker at $220 \mathrm{rpm}$ for $36 \mathrm{~h}$. Then $10 \%$ (v/v) seed culture was inoculated into $50 \mathrm{~mL}$ production 
medium (B medium, g/L: 40 dextrin, 7.5 tomato paste, 2.5 NZ-Amine, 5 yeast extract, $\mathrm{pH} 7.2 \pm 0.2$; $\mathrm{C}$ medium, g/L: 25 glucose, 25 corn flour, 5 yeast extract, $\mathrm{pH} 7.2 \pm 0.2$; F medium, g/L: 100 sucrose, 10 glucose, 5 yeast extract, 0.1 casamino acids, 21 MOPS, trace elements $1 \mathrm{~mL}$, $0.25 \mathrm{~K}_{2} \mathrm{SO}_{4}, 1 \mathrm{MgCl}_{2} \cdot 6 \mathrm{H}_{2} \mathrm{O}, \mathrm{pH} 7.2 \pm 0.2$ ), and then cultured for 7 days at $30{ }^{\circ} \mathrm{C}$ on a rotary shaker at $220 \mathrm{rpm}$. After fermentation for 6 days, 2\% (m/v) XAD-16 resin was added into each flask and then incubated overnight on a rotary shaker at $220 \mathrm{rpm}$. For large-scale fermentation $(8-\mathrm{L}), 50 \mathrm{~mL}$ of seed culture was inoculated into a 2-L Erlenmeyer flask containing $500 \mathrm{~mL}$ of production medium and 16 flasks were used for the fermentation. After the fermentation, the crude extract was exposed to sunlight in air for $2 \mathrm{~h}$, following the same method used previously, to simplify the purification steps of the photosensitive compounds [14].

\section{Extraction, isolation, and purification of rubiginones}

For the analytical-scale fermentation, the supernatant was discarded after centrifugation (3000 rpm, $10 \mathrm{~min}$ ) at room temperature and the resins and bacteria were airdried for 2 days. The resins and bacteria were extracted with $\mathrm{MeOH}(30 \mathrm{~mL} \times 3)$ and evaporated in rotary evaporator at $35{ }^{\circ} \mathrm{C}$, further extracted three times with $30 \mathrm{~mL}$ ethyl acetate (EtOAc) $/ \mathrm{H}_{2} \mathrm{O}(1: 1, \mathrm{v} / \mathrm{v})$, the organic phase was evaporated in rotary evaporator at $35{ }^{\circ} \mathrm{C}$ and dissolved in $1 \mathrm{~mL} \mathrm{MeOH}$ for HPLC analysis. For the largescale fermentation (8-L), the same approach was used to afford the crude extracts $(6.7 \mathrm{~g})$. The crude extracts were subjected to silica gel CC and eluted with a gradient of dichloromethane (DCM)/EtOAc (9:1, 7:1, 5:1, 3:1, 1:1, $\mathrm{v} / \mathrm{v})$ and a gradient of EtOAc/MeOH (8:1, 6:1, 3:1, 1:1, $\mathrm{v} / \mathrm{v}$ ), and pure $\mathrm{MeOH}$, to give ten fractions (Fr. 1-Fr. 10).

Fr. 1 was subjected to silica gel $\mathrm{CC}$ and eluted with a gradient of DCM/EtOAc (40:1, 35:1, 30:1, 20:1, 10:1, 8:1, $5: 1,2: 1,1: 1, \mathrm{v} / \mathrm{v})$, then purified by Sephadex LH-20 chromatography and semi-preparative RP-C18 HPLC with a flow rate of $3 \mathrm{~mL} / \mathrm{min}$ and a gradient elution of $\mathrm{CH}_{3} \mathrm{CN} /$ $\mathrm{H}_{2} \mathrm{O}$ in $15 \mathrm{~min}$ (10\% for $3 \mathrm{~min}, 10 \%$ to $100 \%$ for $4 \mathrm{~min}$, followed by $100 \%$ for $5 \mathrm{~min}$, and $100 \%$ to $10 \%$ for $2 \mathrm{~min}$, followed by $10 \%$ for $1 \mathrm{~min}$ ) to obtain compound 6 (1.2 $\mathrm{mg})$.

Fr. 2 was also subjected to silica gel CC and eluted with a gradient of petroleum ether (PE)/EtOAc (10:1, 6:1, $3: 1,2: 1,1: 1,1: 3, \mathrm{v} / \mathrm{v})$, and pure EtOAc, then purified by Sephadex LH-20 chromatography and semi-preparative $\mathrm{RP}-\mathrm{C} 18 \mathrm{HPLC}$ with a flow rate of $3 \mathrm{~mL} / \mathrm{min}$ and a gradient elution of $\mathrm{CH}_{3} \mathrm{CN} / \mathrm{H}_{2} \mathrm{O}$ in $25 \mathrm{~min}$ ( $10 \%$ for $2 \mathrm{~min}$, $10 \%$ to $80 \%$ for $6 \mathrm{~min}$, followed by $80 \%$ for $2 \mathrm{~min}$, then $80 \%$ to $10 \%$ for $14 \mathrm{~min}$, followed by $10 \%$ for $1 \mathrm{~min}$ ), to afford compound 3 (12.2 mg).
Fr. 4 were subjected to silica gel $C C$, with a gradient of PE/EtOAc (10:1, 8:1, 5:1, 1:1, v/v), and pure EtOAc, and a gradient of EtOAc/MeOH (10:1, 8:1, 1:1, v/v), then purified by Sephadex LH-20 chromatography and semipreparative RP-C18 HPLC with a flow rate of $3 \mathrm{~mL} / \mathrm{min}$ and a gradient elution of $\mathrm{CH}_{3} \mathrm{CN} / \mathrm{H}_{2} \mathrm{O}$ in $25 \mathrm{~min}(30 \%$ for $2 \mathrm{~min}, 30 \%$ to $70 \%$ for $18 \mathrm{~min}$, then $70 \%$ to $100 \%$ for $1 \mathrm{~min}$, followed by $100 \%$ for $1 \mathrm{~min}$, and 100\% to $30 \%$ for $1 \mathrm{~min}$, followed by $30 \%$ for $2 \mathrm{~min}$ ) to obtain compounds 4 (25.6 mg), 7 (3.1 $\mathrm{mg})$ and 8 (2.6 mg).

Fr. 5 were subjected to silica gel $\mathrm{CC}$, with a gradient of EtOAc/MeOH (15:1, 12:1, 8:1, 6:1, 3:1, v/v), compounds 2 $(3.2 \mathrm{mg})$ and $5(1.6 \mathrm{mg})$ were purified by Sephadex LH-20 chromatography and semi-preparative RP-C18 HPLC with a flow rate of $3 \mathrm{~mL} / \mathrm{min}$ and a gradient elution of $\mathrm{CH}_{3} \mathrm{CN} / \mathrm{H}_{2} \mathrm{O}$ in $25 \mathrm{~min}$ (30\% for $2 \mathrm{~min}, 30 \%$ to $50 \%$ for $16 \mathrm{~min}$, then $50 \%$ to $100 \%$ for $2 \mathrm{~min}$, followed by $100 \%$ for $2 \mathrm{~min}$, and $100 \%$ to $30 \%$ for $1 \mathrm{~min}$, followed by $30 \%$ for $2 \mathrm{~min}$ ). Compound 1 (58.8 mg) was purified by silica gel CC, with a gradient of DCM/EtOAc (9:1, 4:1, 7:3, 1:1, 3:7, $\mathrm{v} / \mathrm{v})$, pure EtOAc, and a gradient of EtOAc/MeOH (4:1, $3: 2,3: 7, \mathrm{v} / \mathrm{v})$.

\section{Physicochemical data of compounds 1-8 \\ Rubiginone J (1)}

Light-yellow needles, $[\alpha]_{\mathrm{D}}{ }^{25}+120^{\circ}(c=0.35, \mathrm{MeOH})$; UV $(\mathrm{MeOH}) \lambda_{\max } 212.3,265.9,382.7 \mathrm{~nm}$ (Additional file 1: Fig. S22); HR-ESI-MS $m / z 353.1022[\mathrm{M}+\mathrm{H}]^{+}$ (calcd for $\mathrm{C}_{20} \mathrm{H}_{16} \mathrm{O}_{6}, 353.1020$ ) (Additional file 1: Fig. S10). ${ }^{1} \mathrm{H}$ NMR $\left(400 \mathrm{MHz}, \mathrm{CDCl}_{3}\right) \delta 8.20(\mathrm{~d}, J=12.0 \mathrm{~Hz}$, $1 \mathrm{H}, \mathrm{H}-6), 7.73(\mathrm{~d}, J=12.0 \mathrm{~Hz}, 1 \mathrm{H}, 5-\mathrm{H}), 7.63(\mathrm{t}, J=12.0$, $24.0 \mathrm{~Hz}, 1 \mathrm{H}, 10-\mathrm{H}), 7.58(\mathrm{dd}, J=1.2,11.4 \mathrm{~Hz}, 1 \mathrm{H}, 11-\mathrm{H})$, $7.23(\mathrm{dd}, J=2.4,12.6 \mathrm{~Hz}, 1 \mathrm{H}, 9-\mathrm{H}), 5.29(\mathrm{~d}, J=7.8 \mathrm{~Hz}, 1 \mathrm{H}$, $2-\mathrm{H}), 4.79$ (d, $J=5.4 \mathrm{~Hz}, 1 \mathrm{H}, 4-\mathrm{H}), 3.94\left(\mathrm{~s}, 3 \mathrm{H}, 8-\mathrm{OCH}_{3}\right)$, $2.80(\mathrm{~m}, 1 \mathrm{H}, 3-\mathrm{H}), 0.82\left(\mathrm{~d}, J=10.8 \mathrm{~Hz}, 3 \mathrm{H}, 3-\mathrm{CH}_{3}\right) ;{ }^{13} \mathrm{C}$ NMR (101 MHz, CDCl $) \delta 199.66$ (C-1), 183.97 (C-12), 181.19 (C-7), 160.19 (C-8), 148.14 (C-4a), 137.47 (C-11a), 136.48 (C-6a), 135.99 (C-10), 135.45 (C-12a), 134.72 (C-5), 132.34 (C-12b), 131.72 (C-6), 120.54 (C-7a), 119.96 (C-11), 117.71 (C-9), 73.39 (C-2), 73.16 (C-4), 56.77 (C-8$\left.\mathrm{OCH}_{3}\right), 45.04(\mathrm{C}-3), 10.85\left(3-\mathrm{CH}_{3}\right)$.

\section{Rubiginone K (2)}

Brown oil, UV (MeOH) $\lambda_{\max } 237.5,265.7,288.4,337.4 \mathrm{~nm}$ (Additional file 1: Fig. S22); HR-ESI-MS $m / z$ $[\mathrm{M}+\mathrm{H}]^{+}$(calcd for $\mathrm{C}_{20} \mathrm{H}_{20} \mathrm{O}_{6}, 357.1333$ ) (Additional file 1: Fig. S10). ${ }^{1} \mathrm{H}$ NMR (400 MHz, CD 3 OD) $\delta 8.02(\mathrm{~d}$, $J=8.0 \mathrm{~Hz}, 1 \mathrm{H}, \mathrm{H}-6), 7.61$ (d, $J=8.4 \mathrm{~Hz}, 1 \mathrm{H}, 5-\mathrm{H}), 7.57$ (t, $J=8.0 \mathrm{~Hz}, 1 \mathrm{H}, 10-\mathrm{H}), 7.25(\mathrm{~d}, J=7.2 \mathrm{~Hz}, 1 \mathrm{H}, 11-\mathrm{H})$, 7.08 (d, J=8.4 Hz, 1H, 9-H), $6.62(\mathrm{~s}, 1 \mathrm{H}, 12-\mathrm{H}), 5.33$ (d, $J=4.4 \mathrm{~Hz}, 1 \mathrm{H}, 1-\mathrm{H}), 4.63(\mathrm{~d}, J=7.6 \mathrm{~Hz}, 1 \mathrm{H}, 4-\mathrm{H}), 4.15$ 
(dd, $J=2.8,4.4 \mathrm{~Hz}, 1 \mathrm{H}, 2-\mathrm{H}), 3.88\left(\mathrm{~s}, 3 \mathrm{H}, 8-\mathrm{OCH}_{3}\right), 1.96$ (m, 1H, 3-H), $1.21\left(\mathrm{~d}, J=7.2 \mathrm{~Hz}, 3 \mathrm{H}, 3-\mathrm{CH}_{3}\right) ;{ }^{13} \mathrm{C}$ NMR (101 MHz, CD $\left.{ }_{3} \mathrm{OD}\right) \delta 186.12$ (C-7), 161.45 (C-8), 147.86 (C-11a), 142.86 (C-6a), 146.26 (C-4a), 136.60 (C-12a), 136.13 (C-12b), 134.82 (C-10), 129.47 (C-5), 127.47 (C-6), 123.16 (C-11), 120.87 (C-7a), 112.91 (C-9), 72.69 (C-4), 72.06 (C-2), $68.87(\mathrm{C}-1), 65.18(\mathrm{C}-12), 56.38\left(\mathrm{C}-8-\mathrm{OCH}_{3}\right)$, $41.92(\mathrm{C}-3), 14.77\left(3-\mathrm{CH}_{3}\right)$.

\section{Rubiginone $B_{2}$ (3)}

Light yellow needles, UV (MeOH) $\lambda_{\max } 264.7,377.9 \mathrm{~nm}$ (Additional file 1: Fig. S22); ${ }^{1} \mathrm{H}$ NMR (400 MHz, $\mathrm{CDCl}_{3}$ ) and ${ }^{13} \mathrm{C}$ NMR $\left(101 \mathrm{MHz}, \mathrm{CDCl}_{3}\right)$ see Additional file 1: Figs. S3, S4; HR-ESI-MS m/z $321.1135[\mathrm{M}+\mathrm{H}]^{+}$(calcd $^{2}$ for $\mathrm{C}_{20} \mathrm{H}_{16} \mathrm{O}_{4}, 321.1121$ ) (Additional file 1: Fig. S10).

\section{Rubiginone $A_{2}$ (4)}

Yellow needles, UV (MeOH) $\lambda_{\max } 264.7,381.5 \mathrm{~nm}$ (Additional file 1: Fig. S22); ${ }^{1} \mathrm{H}$ NMR (400 MHz, DMSO- $d_{6}$ ) and ${ }^{13} \mathrm{C}$ NMR (101 MHz, DMSO- $d_{6}$ ) see Additional file 1: Figs. S5, S6; HR-ESI-MS m/z 337.1077 $[\mathrm{M}+\mathrm{H}]^{+}$(calcd for $\mathrm{C}_{20} \mathrm{H}_{16} \mathrm{O}_{5}$, 337.1071) (Additional file 1: Fig. S10).

\section{Rubiginone L (5)}

Brownish-red oil, UV (MeOH) $\lambda_{\max } 224.5,263.4,292.0$, $336.2 \mathrm{~nm}$ (Additional file 1: Fig. S22); HR-ESI-MS $\mathrm{m} / \mathrm{z}$ $341.1390[\mathrm{M}+\mathrm{H}]^{+}$(calcd for $\mathrm{C}_{20} \mathrm{H}_{20} \mathrm{O}_{5}, 341.1384$ ) (Additional file 1: Fig. S30). ${ }^{1} \mathrm{H}$ NMR (500 MHz, $\left.\mathrm{CD}_{3} \mathrm{OD}\right) \delta 8.03$ $(\mathrm{d}, J=8.0 \mathrm{~Hz}, 1 \mathrm{H}, \mathrm{H}-6), 7.72(\mathrm{~d}, J=8.0 \mathrm{~Hz}, 1 \mathrm{H}, 5-\mathrm{H}), 7.60$ (t, $J=8.0 \mathrm{~Hz}, 1 \mathrm{H}, 10-\mathrm{H}), 7.25(\mathrm{~d}, J=7.5 \mathrm{~Hz}, 1 \mathrm{H}, 11-\mathrm{H})$, $7.12(\mathrm{~d}, J=8.5 \mathrm{~Hz}, 1 \mathrm{H}, 9-\mathrm{H}), 6.51(\mathrm{~s}, 1 \mathrm{H}, 12-\mathrm{H}), 5.49(\mathrm{t}$, $J=7.0 \mathrm{~Hz}, 1 \mathrm{H}, 1-\mathrm{H}), 4.35(\mathrm{~d}, J=9.5 \mathrm{~Hz}, 1 \mathrm{H}, 4-\mathrm{H}), 3.91(\mathrm{~s}$, $\left.3 \mathrm{H}, 8-\mathrm{OCH}_{3}\right), 2.36(\mathrm{~m}, 1 \mathrm{H}, 2-\mathrm{H}), 1.73(\mathrm{~m}, 1 \mathrm{H}, 3-\mathrm{H}), 1.60$ (m, $1 \mathrm{H}, 2-\mathrm{H}), 1.19$ (d, $\left.J=7.0 \mathrm{~Hz}, 3 \mathrm{H}, 3-\mathrm{CH}_{3}\right) ;{ }^{13} \mathrm{C}$ NMR $\left(126 \mathrm{MHz}, \mathrm{CD}_{3} \mathrm{OD}\right) \delta 186.33$ (C-7), 161.49 (C-8), 148.53 (C-4a), 147.72 (C-11a), 141.67 (C-12a), 138.51 (C-12b), 136.13 (C-10), 134.51 (C-6a), 127.74 (C-5), 127.37 (C-6), 123.18 (C-11), 121.02 (C-7a), 113.06 (C-9), 75.11 (C-4), 66.61 (C-1), 65.25 (C-12), $56.41\left(\mathrm{C}-8-\mathrm{OCH}_{3}\right), 40.15(\mathrm{C}-2)$, $37.24(\mathrm{C}-3), 19.38\left(3-\mathrm{CH}_{3}\right)$.

\section{Ochromycinoe (6)}

Yellow powder, UV (MeOH) $\lambda_{\max } 265.9,399.6 \mathrm{~nm}$ (Additional file 1: Fig. S22); ${ }^{1} \mathrm{H}$ NMR (500 MHz, $\mathrm{CDCl}_{3}$ ) and ${ }^{13} \mathrm{C}$ NMR $\left(126 \mathrm{MHz}, \mathrm{CDCl}_{3}\right.$ ) see Additional file 1: Figs. S7, S8; HR-ESI-MS m/z $307.0959[\mathrm{M}+\mathrm{H}]^{+}$(calcd for $\left.\mathrm{C}_{19} \mathrm{H}_{14} \mathrm{O}_{4}, 307.0965\right)$ (Additional file 1: Fig. S30).

\section{Rubiginone M (7)}

Brown powder, $[\alpha]_{\mathrm{D}}{ }^{25}+130^{\circ}(c=0.135, \mathrm{MeOH})$; UV $(\mathrm{MeOH}) \lambda_{\max } 265.9,379.1 \mathrm{~nm}$ (Additional file 1: Fig. S22); HR-ESI-MS m/z $337.1072[\mathrm{M}+\mathrm{H}]^{+}$(calcd for $\mathrm{C}_{20} \mathrm{H}_{16} \mathrm{O}_{5}, 337.1071$ ) (Additional file 1: Fig. S30). ${ }^{1} \mathrm{H}$ NMR $\left(600 \mathrm{MHz}, \mathrm{CD}_{3} \mathrm{OD}\right) \delta 8.24(\mathrm{~d}, J=8.4 \mathrm{~Hz}, 1 \mathrm{H}, \mathrm{H}-6), 7.80$ (dd, $J=7.8,8.4 \mathrm{~Hz}, 1 \mathrm{H}, 10-\mathrm{H}), 7.65(\mathrm{t}, J=7.2,15.0 \mathrm{~Hz}$, $1 \mathrm{H}, 11-\mathrm{H}), 7.65(\mathrm{t}, J=7.2,15.0 \mathrm{~Hz}, 1 \mathrm{H}, 5-\mathrm{H}), 7.51(\mathrm{~d}$, $J=8.4 \mathrm{~Hz}, 1 \mathrm{H}, 9-\mathrm{H}), 4.84(\mathrm{~d}, J=4.2 \mathrm{~Hz}, 1 \mathrm{H}, 2-\mathrm{H}), 4.01$ (s, $\left.3 \mathrm{H}, 8-\mathrm{OCH}_{3}\right), 3.41$ (dd, $\left.J=4.8,17.4 \mathrm{~Hz}, 1 \mathrm{H}, 4-\mathrm{H}\right), 3.01$ (dd, $J=4.2,18.0 \mathrm{~Hz}, 1 \mathrm{H}, 4-\mathrm{H}), 2.66(\mathrm{~m}, 1 \mathrm{H}, 3-\mathrm{H}), 0.95$ (d, $\left.J=7.2 \mathrm{~Hz}, 3 \mathrm{H}, 3-\mathrm{CH}_{3}\right) ;{ }^{13} \mathrm{C}$ NMR $\left(151 \mathrm{MHz}, \mathrm{CD}_{3} \mathrm{OD}\right) \delta$ 201.07 (C-1), 185.42 (C-12), 182.69 (C-7), 161.39 (C-8), 150.34 (C-4a), 138.78 (C-11a), 136.98 (C-10), 136.86 (C-6a), 136.06 (C-12a), 135.29 (C-5), 134.99 (C-12b), 130.80 (C-6), 121.41 (C-7a), 120.16 (C-11), 119.04 (C-9), $78.22(\mathrm{C}-2), 55.90\left(\mathrm{C}-8-\mathrm{OCH}_{3}\right), 39.04(\mathrm{C}-3), 36.13$ (C-4), $13.73\left(3-\mathrm{CH}_{3}\right)$.

\section{Rubiginone $N$ (8)}

Brown powder, $[\alpha]_{\mathrm{D}}{ }^{25}+112^{\circ}(c=0.05, \mathrm{MeOH})$; UV $(\mathrm{MeOH}) \lambda_{\max } 264.7,382.7 \mathrm{~nm}$ (Additional file 1: Fig. S22); HR-ESI-MS m/z $395.1132[\mathrm{M}+\mathrm{H}]^{+}$(calcd for $\left.\mathrm{C}_{22} \mathrm{H}_{18} \mathrm{O}_{7}, 395.1125\right)$ (Additional file 1: Fig. S30). ${ }^{1} \mathrm{H}$ NMR $\left(500 \mathrm{MHz}, \mathrm{CD}_{3} \mathrm{OD}\right) \delta 8.36(\mathrm{~d}, J=8.0 \mathrm{~Hz}, 1 \mathrm{H}, \mathrm{H}-6), 7.83$ (m, 1H, 5-H), $7.83(\mathrm{~m}, 1 \mathrm{H}, 11-\mathrm{H}), 7.69(\mathrm{~d}, J=7.5 \mathrm{~Hz}, 1 \mathrm{H}$, $10-\mathrm{H}), 7.54(\mathrm{~d}, J=8.5 \mathrm{~Hz}, 1 \mathrm{H}, 9-\mathrm{H}), 6.08(\mathrm{~d}, J=3.0 \mathrm{~Hz}$, $1 \mathrm{H}, 4-\mathrm{H}), 5.16(\mathrm{~d}, J=4.5 \mathrm{~Hz}, 1 \mathrm{H}, 2-\mathrm{H}), 4.02(\mathrm{~s}, 3 \mathrm{H}$, 8- $\left.\mathrm{OCH}_{3}\right), 2.76(\mathrm{~m}, 1 \mathrm{H}, 3-\mathrm{H}), 2.13\left(\mathrm{~s}, 1 \mathrm{H}, 4-\mathrm{OCOCH}_{3}\right)$, $0.95\left(\mathrm{~d}, J=7.0 \mathrm{~Hz}, 3 \mathrm{H}, 3-\mathrm{CH}_{3}\right) ;{ }^{13} \mathrm{C}$ NMR $(126 \mathrm{MHz}$, $\left.\mathrm{CD}_{3} \mathrm{OD}\right) \delta 199.59(\mathrm{C}-1), 185.02$ (C-12), 182.24 (C-7), $171.78\left(4-\mathrm{OCOCH}_{3}\right), 161.54$ (C-8), 145.65 (C-4a), 138.68 (C-11a), 137.92 (C-10), 137.16 (C-6a), 136.82 (C-12a), 135.90 (C-5), 135.72 (C-12b), 131.61 (C-6), 121.48 (C-7a), 120.21 (C-11), 119.21 (C-9), 75.35 (C-2), 74.79 (C-4), $56.95\left(\mathrm{C}-8-\mathrm{OCH}_{3}\right), 44.22(\mathrm{C}-3), 20.94\left(4-\mathrm{OCO}^{-} \mathrm{H}_{3}\right)$, $11.10\left(3-\mathrm{CH}_{3}\right)$.

\section{Gene inactivations in Streptomyces sp. CB02414}

A pOJ260-based plasmid Y0002 was constructed to generate the $\triangle r u b F 1 / r u b F 2$ replacement mutant in CB02414 via a double crossover homologous recombination. To inactivate $r u b F 1 / r u b F 2$, a partial fragment spanning these two genes was replaced with the kanamycin-resistance gene using the Seamless Cloning and Assembly kit (TSINGKE, China), and the mutated rubF1/rubF2 was cloned into pOJ260 between the XbaI and Hin$d$ III restriction sites. This plasmid was introduced into CB02414 (wild-type) and Z0001 (i.e., CB02414_orf3/ orf4) by intergeneric conjugation, then selected for kanamycin-resistance and apramycin-sensitive phenotype to obtain the desired double-crossover mutants Z0002 (i.e., $\mathrm{CB} 02414 \Delta r u b F 1 / r u b F 2$ ) and Z0003 (i.e., Z0001 $\Delta r u b F 1 /$ rubF2), respectively. Deletion of orf3/orf4, rubN1, rubN2 and rubM4 in CB02414 was conducted via in-frame deletion, to obtain mutants Z0001, Z0004, Z0005 and Z0008, respectively. The mutants were confirmed by PCR analysis and DNA sequencing. The strains and plasmids were 
shown in Additional file 1: Table S9, the PCR primers were shown in Additional file 1: Table S10, schematic diagram for the gene inactivations and PCR confirmation of the mutant strains were shown in Additional file 1: Figs. S1, S53, respectively.

\section{Complementation in Z0004, Z0005 and Z0008.}

For the complementation of rubN1, a pSET152-based plasmid Y0005, in which rubN1 was cloned under the control of the constitutive promoter ermE* was constructed. The rubN1 was PCR-amplified by the Q5 high-fidelity DNA polymerase using genomic DNA of CB02414 wild-type as template, and the resultant PCR fragment was inserted into the pSET152 between $\mathrm{XbaI}$ and BamHI restriction sites. This plasmid Y0005 was then introduced into Z0004 (i.e., CB02414 $\Delta r u b N 1$ ) by intergeneric conjugation and selected for apramycin resistant conjugants to afford Z0006 (i.e., Z0004::rubN1). The complementation strains Z0007 (i.e., Z0005::rubN2) and Z0009 (i.e., Z0008::rubM4) were obtained by using the same method. The PCR primers used in the complementation experiments are shown in Additional file 1: Table S10.

\section{Supplementary Information}

The online version contains supplementary material available at https://doi. org/10.1186/s12934-021-01681-5.

Additional file 1. Additional Tables S1-S10, Figures S1-S53.

\section{Acknowledgements}

Not applicable.

\section{Authors' contributions}

YXH and DYW designed the study; ZJY, SY, WYJ, CX, XL, ZJJ and ZXC performed the experiments and acquired all data; YXH, ZJY and DYW analyzed and interpreted the data; YXH and ZJY wrote the manuscript. All authors read and approved the final manuscript.

\section{Funding}

This research was supported by the National Natural Science Foundation of China (NFSC, Grant 81872779), and the Fundamental Research Funds for the Central Universities of Central South University $2020 z z t s 837$.

\section{Availability of data and materials}

All data generated or analyzed during this study are included in this published article.

\section{Declarations}

\section{Ethics approval and consent to participate}

Not applicable. The manuscript does not contain data collected from humans or animals.

\section{Consent for publication}

Not applicable.

\section{Competing interests}

The authors declare that they have no competing interests.

\section{Author details}

${ }^{1}$ Xiangya International Academy of Translational Medicine, Central South University, Tongzipo Road, \#172, Yuelu District, Changsha 410013, Hunan, China. ${ }^{2}$ State Key Laboratory of Component-Based Chinese Medicine, Tianjin University of Traditional Chinese Medicine, Tianjin, China. ${ }^{3}$ Hunan Engineering Research Center of Combinatorial Biosynthesis and Natural Product Drug Discovery, Changsha, Hunan, China. ${ }^{4}$ National Engineering Research Center of Combinatorial Biosynthesis for Drug Discovery, Changsha, Hunan, China.

Received: 4 July 2021 Accepted: 15 September 2021

Published online: 02 October 2021

\section{References}

1. Rohr J, Thiericke R. Angucycline group antibiotics. Nat Prod Rep. 1992;9:103-37.

2. Kuntsmann MP, Mitscher LA. The structural characterization of tetrangomycin and tetrangulol. J Org Chem. 1966;31:2920-5.

3. Metsä-Ketelä M, Palmu K, Kunnari T, Ylihonko K, Mäntsälä P. Engineering anthracycline biosynthesis toward angucyclines. Antimicrob Agents Chemother. 2003:47:1291-6.

4. Rix U, Remsing LL, Hoffmeister D, Bechthold A, Rohr J. Urdamycin L: a novel metabolic shunt product that provides evidence for the role of the urdM gene in the urdamycin A biosynthetic pathway of Streptomyces fradiae TÜ 2717. ChemBioChem. 2003;4:109-11.

5. Kallio P, Liu ZL, Mäntsälä P, Niemi J, Metsä-Ketelä M. Sequential action of two flavoenzymes, PgaE and PgaM, in angucycline biosynthesis: chemoenzymatic synthesis of gaudimycin C. Chem Biol. 2008;15:157-66.

6. Kharel MK, Nybo SE, Shepherd MD, Rohr J. Cloning and characterization of the ravidomycin and chrysomycin biosynthetic gene clusters. ChemBioChem. 2010;11(4):523-32.

7. Trefzer A, Fischer C, Stockert S, Westrich L, Künzel E, Girreser U, Rohr J, Bechthold A. Elucidation of the function of two glycosyltransferase genes (IanGT1 and lanGT4) involved in landomycin biosynthesis and generation of new oligosaccharide antibiotics. Chem Biol. 2001;8:1239-52.

8. von Mulert U, Luzhetskyy A, Hofmann C, Mayer A, Bechthold A. Expression of the landomycin biosynthetic gene cluster in a PKS mutant of Streptomyces fradiaeis dependent on the coexpression of a putative transcriptional activator gene. FEMS Microbiol Lett. 2004;230(1):91-7.

9. Kharel MK, Pahari P, Shepherd MD, Tibrewal N, Nybo SE, Shaaban KA, Rohr J. Angucyclines: biosynthesis, mode-of-action, new natural products, and synthesis. Nat Prod Rep. 2012;29(2):264-325.

10. Oka M, Kamei H, Hamagishi Y, Tomita K, Miyaki T, Konishi M. Chemical and biological properties of rubiginone, a complex of new antibiotics with vincristine-cytotoxicity potentiating activity. J Antibiot (Tokyo). 1990;43(8):967-76.

11. Ogasawara M, Hasegawa M, Hamagishi Y, Kamei H, Oki T. Potentiation of vincristine cytotoxicity by rubiginone $\mathrm{B} 1$ and piperafizine $\mathrm{A}$ in human Moser and K562 cells-mode of action. J Antibiot (Tokyo). 1992;45(1):129-32.

12. Kimura K, Kanou F, Koshino H, Uramoto M, Yoshihama M. SNA-8073-B, a new isotetracenone antibiotic inhibits prolyl endopeptidase. I. Fermentation, isolation and biological properties. J Antibiot (Tokyo). 1997:50(4):291-6.

13. Boonlarppradab C, Suriyachadkun C, Rachtawee P, Choowong W, Saccharosporones A. B and C, cytotoxic antimalarial angucyclinones from Saccharopolyspora sp. BCC 21906. J Antibiot (Tokyo). 2013;66(6):305-9.

14. Puder C, Zeeck A, Beil W. New biologicallly active rubiginones from Streptomyces sp. J Antibiot (Tokyo). 2000;53(4):329-36.

15. Hayakawa Y, Ha SC, Kim YJ, Furihata K, Seto H. Studies on the isotetracenone antibiotics. IV. Hatomarubigins A, B, C and D, new isotetracenone antibiotics effective against multidrug-resistant tumor cells. J Antibiot (Tokyo). 1991;44(11):1179-86.

16. Kawasaki T, Hirashima R, Maruta T, Sato H, Maeda A, Yamada Y, Takeda M, Hayakawa Y. Cloning and characterization of a gene cluster for hatomarubigin biosynthesis in Streptomyces sp. strain 2238-SVT4. Appl Environ Microbiol. 2010;76(13):4201-6.

17. Yan X, Ge HM, Huang TT, Hindra, Yang D, Teng QH, Crnovčić I, Li XL, Rudolf JD, Lohman JR, Gansemans Y, Zhu XC, Huang Y, Zhao LX, Jiang Y, Van Nieuwerburgh F, Rader C, Duan YW, Shen B. Strain 
prioritization and genome mining for enediyne natural products. MBio. 2016;7(6):e02104-16.

18. Blin K, Shaw S, Kloosterman AM, Charlop-Powers Z, van Wezel GP, Medema MH, Weber T. antiSMASH 6.0: improving cluster detection and comparison capabilities. Nucleic Acids Res. 2021:49:W29-35.

19. Kelemen GH, Brian P, Flärdh K, Chamberlin L, Chater KF, Buttner MJ. Developmental regulation of transcription of whiE, a locus specifying the polyketide spore pigment in Streptomyces coelicolor A3 (2). J Bacteriol. 1998:180(9):2515-21.

20. Ōmura S, Ikeda H, Ishikawa J, Hanamoto A, Takahashi C, Shinose M, Takahashi Y, Horikawa H, Nakazawa H, Osonoe T, Kikuchi H, Shiba T, Sakaki Y, Hattori M. Genome sequence of an industrial microorganism Streptomy ces avermitilis: deducing the ability of producing secondary metabolites. Proc Natl Acad Sci USA. 2001;98(21):12215-20.

21. Bergh S, Uhlen M. Analysis of a polyketide synthesis-encoding gene cluster of Streptomyces curacoi. Gene. 1992;117(1):131-6.

22. Wang S, Zhao R, Liu K, Zhu M, Li A, He J. Essential role of an unknown gene aziU3 in the production of antitumor antibiotic azinomycin $B$ verified by utilizing optimized genetic manipulation systems for Streptomyces sahachiroi. FEMS Microbiol Lett. 2012:337(2):147-54.

23. Yan $X$, Probst K, Linnenbrink A, Arnold M, Paululat T, Zeeck A, Bechthold A. Cloning and heterologous expression of three type II PKS gene clusters from Streptomyces bottropensis. ChemBioChem. 2012;13(2):224-30.

24. Novakova R, Bistakova J, Kormanec J. Characterization of the polyketide spore pigment cluster whiESa in Streptomyces aureofaciens CCM3239. Arch Microbiol. 2004;182(5):388-95.

25. Bowie JH, Johnson AW. The structure of ochromycinone. Tetrahedron Lett. 1967:8(16):1449-52.

26. Bertolt G, Govind C, Dagmara J, Tian YQ, Celia JB, Keith FC. Lambda redmediated genetic manipulation of antibiotic-producing Streptomyces. Adv Appl Microbiol. 2004;54:107-28.

27. de Jong A, van Hijum SA, Bijlsma JJ, Kok J, Kuipers OP. BAGEL: a web-based bacteriocin genome mining tool. Nucleic Acids Res. 2006;34:W273-9.
28. Skinnider MA, Merwin NJ, Johnston CW, Magarvey NA. PRISM 3: expanded prediction of natural product chemical structures from microbial genomes. Nucleic Acids Res. 2017:45:W49-54.

29. Starcevic A, Zucko J, Simunkovic J, Long PF, Cullum J, Hranueli D. ClustScan: an integrated program package for the semi-automatic annotation of modular biosynthetic gene clusters and in silico prediction of novel chemical structures. Nucleic Acids Res. 2008;36:6882-92.

30. Weber T, Rausch C, Lopez P, Hoof I, Gaykova V, Huson DH, Wohlleben W. CLUSEAN: a computer-based framework for the automated analysis of bacterial secondary metabolite biosynthetic gene clusters. J Biotechnol. 2009;140:13-7.

31. Lee N, Hwang SK, Kim JH, Cho SH, Palsson B, Cho BK. Mini review: genome mining approaches for the identification of secondary metabolite biosynthetic gene clusters in Streptomyces. Comput Struct Biotechnol J. 2020;18:1548-56.

32. Pan GH, Gao XQ, Fan KQ, Liu JL, Meng B, Gao JM, Wang B, Zhang CB, Han $\mathrm{H}, \mathrm{Ai} \mathrm{GM}$, Chen YH, Wu D, Liu ZJ, Yang KQ. Structure and function of a $\mathrm{C}-\mathrm{C}$ bond cleaving oxygenase in atypical angucycline biosynthesis. ACS Chem Biol. 2017;12(1):142-52.

33. Faust $B$, Hoffmeister D, Weitnauer $G$, Westrich $L$, Haag $S$, Schneider $P$, Decker H, Kunzel E, Rohr J, Bechthold A. Two new tailoring enzymes, a glycosyltransferase and an oxygenase, involved in biosynthesis of the angucycline antibiotic urdamycin A in Streptomyces fradiae Tü2717. Microbiology. 2000;146(Pt 1):147-54.

34. Oka M, Konishi M, Oki T, Ohashi M. Absolute configuration of the rubiginones and photo-induced oxidation of the $\mathrm{C} 1$ hydroxyl of the antibiotics to a ketone. Tetrahedron Lett. 1990;31(51):7473-7.

\section{Publisher's Note}

Springer Nature remains neutral with regard to jurisdictional claims in published maps and institutional affiliations.
Ready to submit your research? Choose BMC and benefit from:

- fast, convenient online submission

- thorough peer review by experienced researchers in your field

- rapid publication on acceptance

- support for research data, including large and complex data types

- gold Open Access which fosters wider collaboration and increased citations

- maximum visibility for your research: over $100 \mathrm{M}$ website views per year

At BMC, research is always in progress.

Learn more biomedcentral.com/submissions 